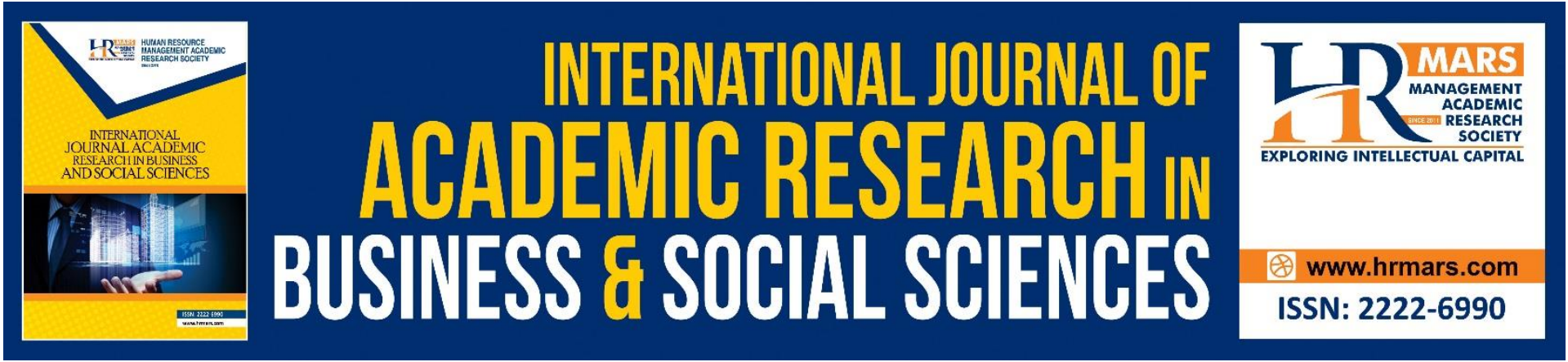

\title{
"e-learning on the Go": Understanding the Knowledge, Attitudes, and Motivations of Students of the Beauty and Spa Therapy Program
}

\section{Quah Wei Boon, Norashikin Abdullah}

To Link this Article: http://dx.doi.org/10.6007/IJARBSS/v11-i10/10862

DOI:10.6007/IJARBSS/v11-i10/10862

Received: 14 August 2021, Revised: 11 September 2021, Accepted: 21 September 2021

Published Online: 03 October 2021

In-Text Citation: (Quah \& Abdullah, 2021)

To Cite this Article: Quah, W. B., \& Abdullah, N. (2021). "e-learning on the Go": Understanding the Knowledge, Attitudes, and Motivations of Students of the Beauty and Spa Therapy Program. International Journal of Academic Research in Business and Social Sciences, 11(10), 274-285.

Copyright: (c) 2021 The Author(s)

Published by Human Resource Management Academic Research Society (www.hrmars.com)

This article is published under the Creative Commons Attribution (CC BY 4.0) license. Anyone may reproduce, distribute, translate and create derivative works of this article (for both commercial and non-commercial purposes), subject to full attribution to the original publication and authors. The full terms of this license may be seen at: http://creativecommons.org/licences/by/4.0/legalcode

Vol. 11, No. 10, 2021, Pg. 274 - 285

Full Terms \& Conditions of access and use can be found at http://hrmars.com/index.php/pages/detail/publication-ethics 


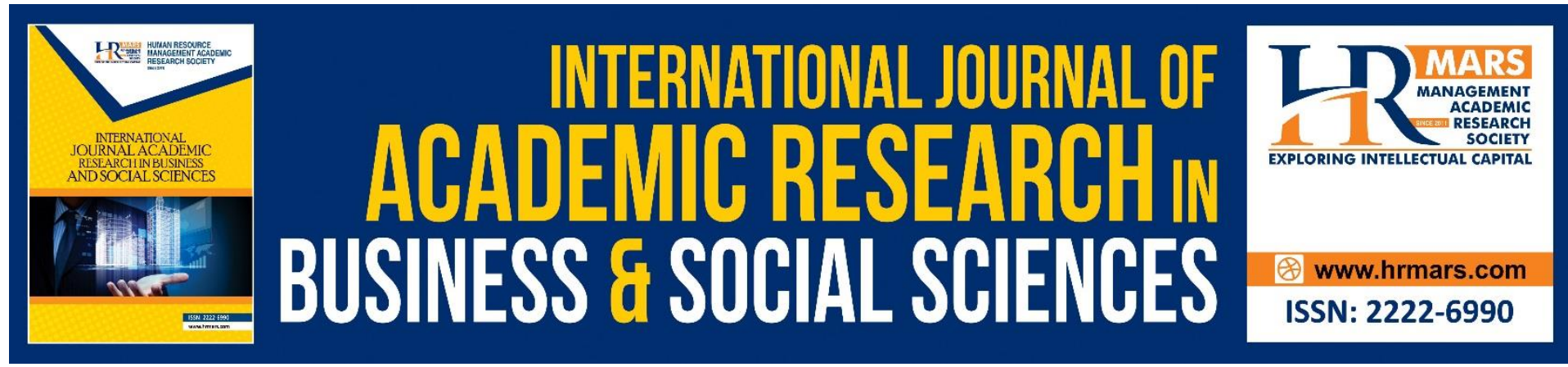

\title{
"e-learning on the Go": Understanding the Knowledge, Attitudes, and Motivations of Students of the Beauty and Spa Therapy Program
}

\author{
Quah Wei Boon ${ }^{1}$, Norashikin Abdullah ${ }^{2}$ \\ ${ }^{1}$ Unit Hotel Operation, Sungai Petani Community College, 08000 Kedah, Malaysia, ${ }^{2}$ Unit \\ Beauty and Spa Therapy, Sungai Petani Community College, 08000 Kedah, Malaysia \\ Email: skyman823000@yahoo.com,kkspshikin@gmail.com
}

\begin{abstract}
In the digital age of the latest revolution, education is not left behind in transforming to digital andragogy and pedagogy. This study aims to identify the students' level of knowledge, attitude, and motivation in the readiness of e-learning at Sungai Petani Community College. The study also identified whether there is a difference between the Certificate in Beauty and Spa programs and the Diploma in Beauty Therapy in influencing students' level of knowledge, attitude, and motivation towards the use of e-learning. Respondents comprised of 92 students of Certificate in Beauty and Spa Therapy and Diploma in Beauty Therapy at Sungai Petani Community College using a questionnaire. The results showed that the student's knowledge, attitude, and motivation were at a high level with a mean ( $M=3.98)$ respectively; $M=3.95 ; M=3.93)$. The test-t analysis showed that there was no significant difference in the level of knowledge, student attitude, and motivation between the Certificate in Beauty and Spa programs and the Diploma in Beauty Therapy. This study implies that the skills and knowledge of students with the use of digital platforms still need to be applied by these lecturers as the implementation of e-learning is a long-term journey due to the unfinished covid-19 pandemic. In addition, lecturers should use various digital platforms to maintain students' interest and encourage students to use e-learning.
\end{abstract}

Keywords: E-Learning, Knowledge, Attitude, Motivation, Beauty Therapy, and Spa

\section{Introduction}

According to Anuar Ahmad, Lecturer of the Centre for Education and Community Well-being, The National University of Malaysia (UKM), if e-learning was previously only an option, but with the enforcement of the Movement Control Order (MCO), it would be a necessity (Bernama, 2020). As the MCO period is still extended, e-learning is no longer an option but it has become a necessity as students are still in their homes. To ensure that all students are not left behind in their learning, educators begin using the option to run classes online. There is various disgust that arises when implementing e-learning methods from both the educators and students. Among them, some students lack or do not have the skills to use digital platforms or e-learning applications (Doman, 2017), some students are less comfortable with e-learning methods or anxiety related to the use of technology (Gillett-Swan, 2017), some 
students do not have enough Internet data (Sarvestani et al., 2019; Siddiquah \& Salim, 2017) and some students do not have direct Internet access (Hamat, Mahlan, \& Ch'ng, 2020) as well as unattractive e-content and cannot spark interest among students (Yahaya, 2018). From the issues mentioned, the three main implications that can be seen to be a challenge for the students of Beauty Therapy and Spa at Sungai Petani Community College to conduct elearning are related to the level of student knowledge, student attitude, and motivation of the students towards readiness in the use of e-learning.

In line with the MCO order implemented by the Malaysian government to curb the spread of COVID-19, e-learning is a necessity. Most local universities, both public and private, including schools in Malaysia, have no other choice by using virtual learning methods to ensure that the teaching syllabus can be delivered as best they can and that learning sessions are not postponed. Sungai Petani Community College (KKSP) is no exception to e-learning although the institution is more focused on learning $70 \%$ practical. Lecturers started implementing elearning using the platform introduced by the E-learning unit of the Sungai Petani Community College that is Google Classroom. Based on the implications mentioned earlier, this study was conducted to identify students of Certificate of Beauty and Spa Therapy and Diploma in Beauty Therapy at Sungai Petani Community College on the use of e-learning among students in terms of knowledge, attitude, and motivation. Specifically, there are two objectives as follows:

i. To identify the level of knowledge of students of the Beauty and Spa Therapy Certificate and The Diploma in Beauty Therapy towards the use of e-learning.

ii. To identify the level of attitudes of students of the Beauty and Spa Therapy Certificate and The Diploma in Beauty Therapy towards the use of e-learning.

iii. To identify the level of motivations of students of the Beauty and Spa Therapy Certificate and The Diploma in Beauty Therapy towards the use of e-learning.

iv. To identify whether there is a difference between the Beauty and Spa Therapy Certificate program and the Diploma in Beauty Therapy affects students' level of knowledge, attitude, and motivation towards the use of e-learning.

\section{Research Hypothesis}

Ho1: There is no significant difference between knowledge levels based on the Certificate and Diploma in Beauty Therapy program.

Ho2: There is no significant difference between student attitude levels based on the Certificate and Diploma in Beauty Therapy program.

Ho3: There is no significant difference between motivation based on the Certificate and Diploma in Beauty Therapy program.

\section{Literature Review}

E-learning is known as electronic learning using electronic devices such as mobile phones, computers, and other devices (Suri, Subagyo, \&Irwansyah, 2021). Furthermore, e-learning is also an approach to learning the medium of technology with the use of information and communication technology (ICT) (Valverde-Berrocoso, Garrido-Arroyo, Burgos-Videla \& Morales-Cevallos, 2020) to facilitate and improve the teaching and learning experience (T\&L) (Ibrahim, Abu Hassan, \& Othman, 2016). From the study, Ouma (2020) also stated that elearning is used to increase academic potential in electronic learning patterns. This is because 
E-learning can create a digital learning space (Kurniawansyah \& Siswanto, 2020). In addition, the knowledge and skills of students are often associated with aspects of students' willingness the use E-learning (Lapammu \& Mahamod, 2018). The Doman Study (2017) also states that high skills and knowledge need to manifest themselves in students with the use of technology in the teaching and learning process. Therefore, the T\&L process will be affected if students lack the skills and knowledge related to internet use (Abd Manaf et al., 2015). Meanwhile, the study of Ibrahim et al (2016) also stated that the level of knowledge, attitude, and motivation of students is an important element in identifying students' willingness to use e-learning. Furthermore, the Yahaya and Ling study (2011), also stated that a lack of student knowledge in the use of e-learning will be an obstacle to students when using e-learning. Not only that, Yahaya and Ling (2011) also stated that students' attitudes and motivations also play a role in their willingness to use e-learning. In conclusion, based on the results of past studies, it can be formulated that the student's level of knowledge, student attitude, and student motivation level are important elements to be identified in the study of willingness in the use of elearning.

\section{Beauty \& Spa Therapy Program}

The Beauty Therapy and Spa program is a program offered at the community college, Ministry of Higher Education Malaysia. This program is one of the programs that enable students to acquire knowledge and skills not only in theory but also practically in the field of facial treatments, hand and foot spas, professional make-up of body spa, and spa management. With the knowledge and skills gained, it will help and be able to prepare students for the real world of work in the beauty and spa industry. In addition, the program also exposes students to the entrepreneurial aspect so that students can be more involved in careers in this field. Students are also exposed to techniques of communicating and handling customers' beauty problems effectively. The program also provided skills for students on the use of electrotherapy machines to expedite the process of tackling beauty problems such as sagging skin problems, pigmentation, acne, fat removal, and weight loss. Students are taught to use electrotherapy machines with the right techniques according to customer problems. For students who are interested in body massage, several types of massage techniques will be taught such as relaxing massage, Swedish massage, and special massage which is Malaysian massage. In the third semester, students will be stressed with spa management courses and spa concepts to ensure students are not left behind to manage the spa with other competitors in the real business world. At the end of the semester, students will undergo 6 months of industrial training to further enhance the knowledge and skills learned in the communal college. Some of the job opportunities offered to students upon completion of industrial training are, such as image consultants, beauty engineers, aesthetic engineers, solvers, spa supervisors, product entrepreneurs (founder).

\section{The Use of Google Classroom as a Platform for E-learning}

The Google Classroom platform was introduced by the E-learning Unit of the KKSP as a Helpdesk to help lecturers to implement e-learning. As this is the first time, the lecturers have face-to-face teaching and learning (T\&L) switch to the e-learning platform. This E-learning unit was established to offer assistance to all lecturers from all technical aspects of e-learning usage if experiencing problems in conducting e-learning classes. Lecturers have used the Google Classroom platform as a "one-stop center" to share materials/notes for each topic, assign assignments to students, upload videos related to topics, make announcements for 
classes, make discussions with students and evaluate them using this platform. Here are some examples of the Google Classroom screenshots that have been used by lecturers in Beauty Therapy and Spa.

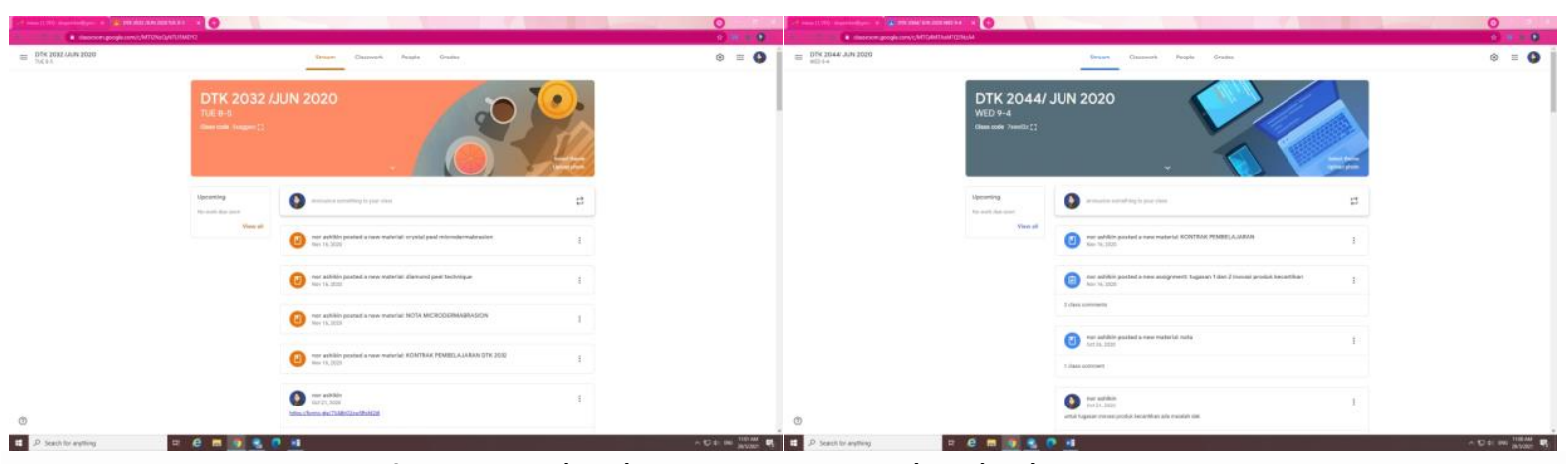

Fig. 1 Google Classroom screenshot by lecturer $A$

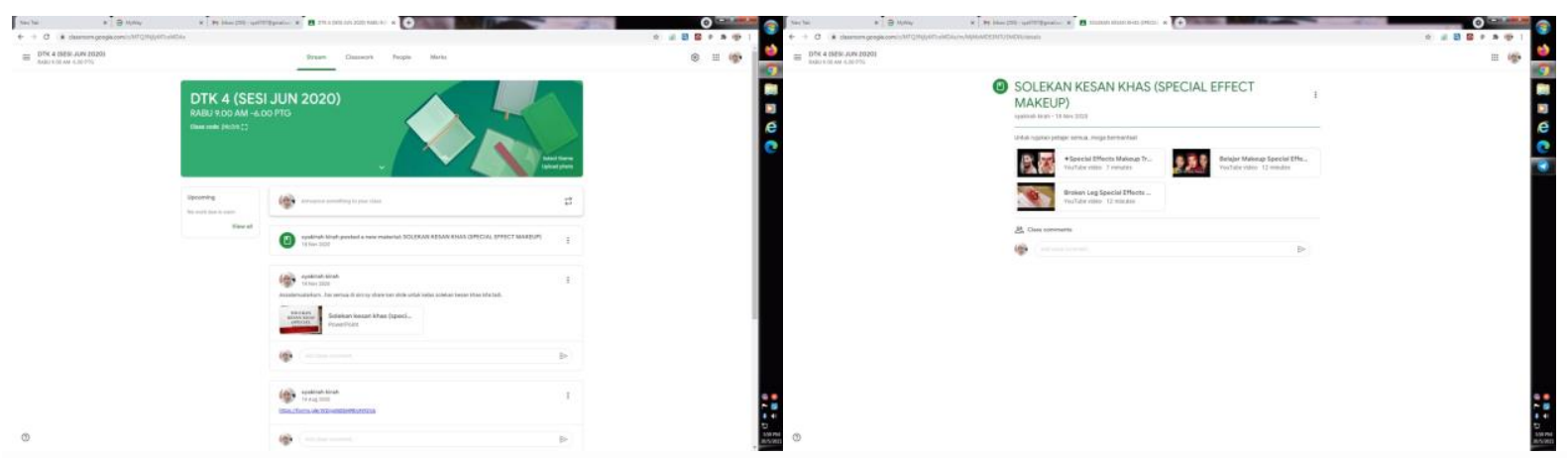

Fig. 2 Google Classroom screenshot by lecturer B

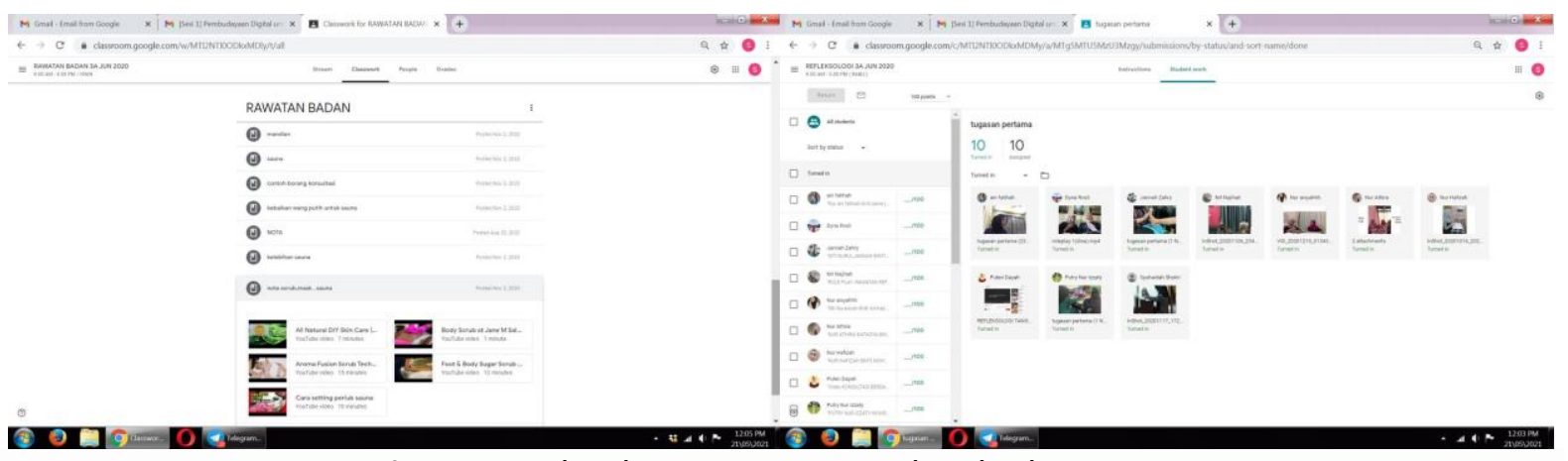

Fig. 3 Google Classroom screenshot by lecturer C 


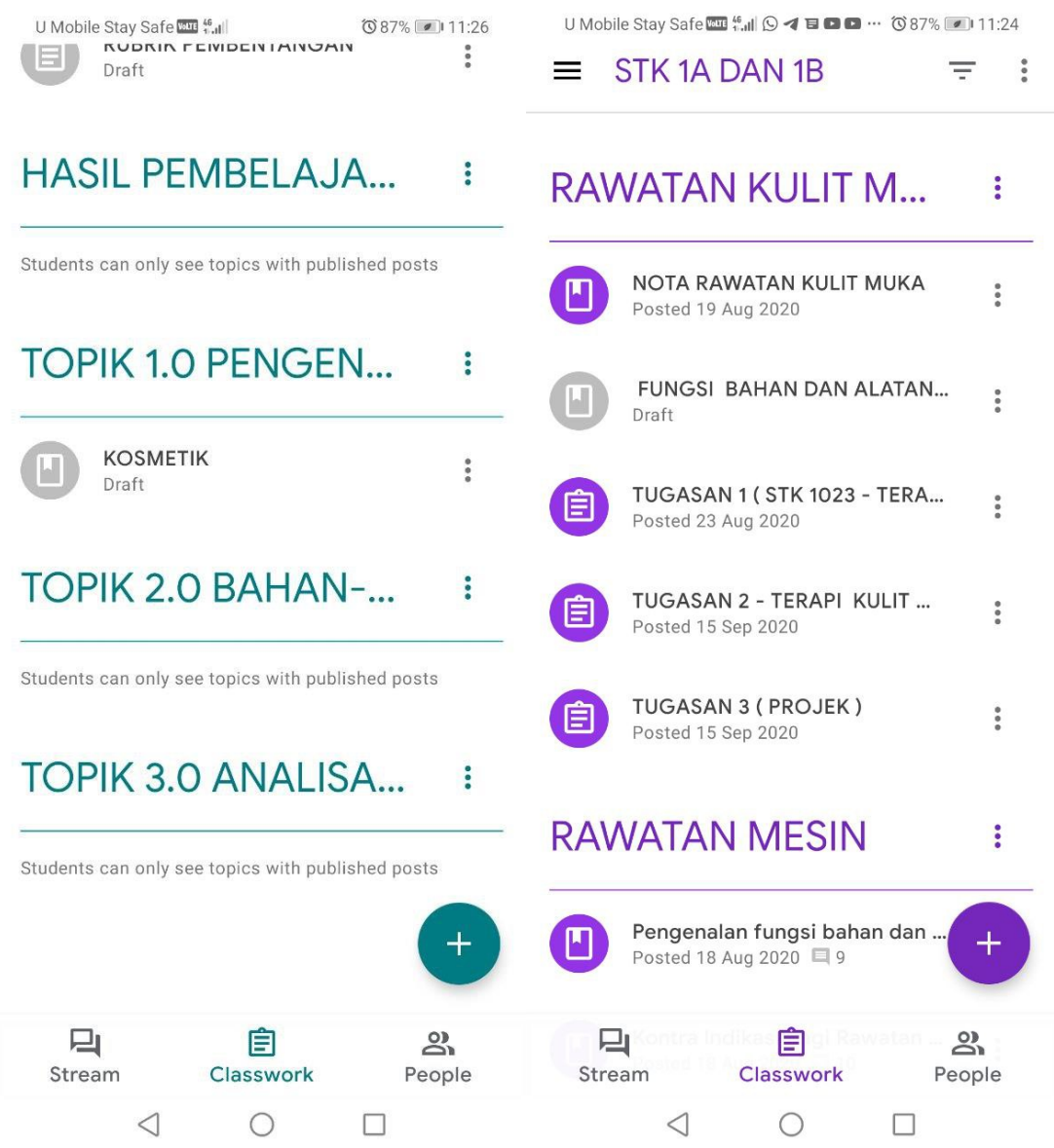

Fig. 4 Google Classroom screenshot by lecturer D

\section{Methodology}

In this study, the study population consisted of students of Certificate of Beauty and Spa Therapy and Diploma in Beauty Therapy of Sungai Petani Community College in June 2020. The sample samples recommended by Krejcie and Morgan (1970) were 80 people, which was $79.2 \%$ of the total population of 101 people. In this study, the total number of respondents who answered the questionnaire was 92 people which was $91.1 \%$. The instruments used are in the form of questionnaires adapted and modified from the Yahaya and Ning studies (2011) and are divided into 2 parts. Part $A$ is a student demographic that seeks to obtain background information of the respondents. Part B consists of a questionnaire using the Likert Scale method on questions on e-learning knowledge level, students' attitude towards the use of elearning, and the motivation of students towards the use of e-learning. Data obtained from the Likert scale is five points ( 1 - strongly disagree, 2 - disagree, - 3 slightly disagree, 4 - agree, 5 - strongly agree). Students' level of knowledge and attitude and motivation are interpreted based on scores that are recoded to three levels of awareness, low, medium, and high awareness. The mean interpretation is shown in table 1.

Table 1: Mean Interpretation

\begin{tabular}{|l|l|}
\hline Mean Range & Interpretation \\
\hline $3.68-5.00$ & High \\
\hline $2.34-3.67$ & Medium \\
\hline $1.00-2.33$ & Low \\
\hline
\end{tabular}




\section{Findings}

Table 2 shows that all 13 items on students' knowledge level of e-learning have a mean score ranging from $3.75-4.20$. Item 1 (I have the skills to use e-learning) and item 2 (I always face obstacles when using e-learning because of the constraints of knowledge using it) have the lowest mean scores of 3.75 and 3.76 respectively. Item 6 (I know that many learning materials are available through e-learning) and the remaining 10 items have the highest mean score of 4.20 and above 3.77 scores respectively.

Table 2: Mean distribution of students' knowledge towards the use of e-learning for the Certificate in Beauty and Spa Program and Diploma in Beauty Therapy

\begin{tabular}{|l|l|c|c|c|}
\hline No. & Item & Mean & SP & Level \\
\hline 1 & I have the skills to use e-learning & 3.75 & .807 & High \\
\hline 2 & $\begin{array}{l}\text { I always encounter obstacles when using e-learning because of } \\
\text { the constraints of knowledge using it }\end{array}$ & 3.76 & .803 & High \\
\hline 3 & I am aware that e-learning is applied in KKSP & 4.05 & .817 & High \\
\hline 4 & I realized that e-learning has many advantages. & 4.15 & .825 & High \\
\hline 5 & I know that I will miss it if I do not use e-learning. & 4.04 & .913 & High \\
\hline 6 & $\begin{array}{l}\text { I know that many learning materials are available through e- } \\
\text { learning }\end{array}$ & 4.20 & .815 & High \\
\hline 7 & I know that e-learning can help my academic achievements. & 4.11 & .895 & High \\
\hline 8 & I realized that I needed to use e-learning while I was at KKSP. & 4.11 & .818 & High \\
\hline 9 & I can use e-learning effectively & 3.96 & .797 & High \\
\hline 10 & I have ICT skills. & 3.80 & .867 & High \\
\hline 11 & I have knowledge of ICT. & 3.80 & .917 & High \\
\hline 12 & I know that e-learning is a necessity. & 4.18 & .783 & High \\
\hline 13 & I feel confident when using e-learning. & 3.80 & .829 & High \\
\hline & Total Mean & 3.98 & .625 & High \\
\hline
\end{tabular}

Table 3 shows the mean score for students' attitudes towards e-learning usage. The overall mean is 3.95, which is at a high level. The item that obtained the highest mean was item 11, which is 4.30 , while item 2 is the lowest mean item of the mean value, at 3.43. 
Table 3: Mean distribution of students' attitude towards the use of e-learning for Beauty and Spa Therapy Certificate Program and Diploma in Beauty Therapy

\begin{tabular}{|l|l|c|c|c|}
\hline No. & Item & Mean & SP & Level \\
\hline 1 & I'm ready to use e-learning at any time. & 4.03 & .791 & High \\
\hline 2 & I use e-learning regularly (more than 5 times a week). & 3.43 & .905 & Medium \\
\hline 3 & I always learn how to use e-learning. & 3.71 & .932 & High \\
\hline 4 & $\begin{array}{l}\text { I am always concerned about the current issues raised by } \\
\text { KKSP e-learning. }\end{array}$ & 4.02 & .784 & High \\
\hline 5 & I am ready to face the challenges in the use of e-learning. & 4.03 & .805 & High \\
\hline 6 & I often encourage my friends to use e-learning. & 3.83 & .847 & High \\
\hline 7 & $\begin{array}{l}\text { I consider that e-learning is my preferred method of } \\
\text { learning. }\end{array}$ & 3.84 & .905 & High \\
\hline 8 & I use e-learning for all courses. & 3.86 & .990 & High \\
\hline 9 & I use e-learning to communicate with classmates. & 3.90 & .950 & High \\
\hline 10 & I use e-learning to communicate with the lecturers. & 4.16 & .802 & High \\
\hline $\mathbf{1 1}$ & $\begin{array}{l}\text { I always try to use e-learning to get notes \& other learning } \\
\text { materials. }\end{array}$ & $\mathbf{4 . 3 0}$ & $\mathbf{. 7 5 2}$ & High \\
\hline 12 & I always take opportunities in learning through e-learning. & 4.28 & .731 & High \\
\hline & \multicolumn{1}{|c|}{ Total Mean } & $\mathbf{3 . 9 5}$ & .679 & High \\
\hline
\end{tabular}

Table 4 shows the min score for the student's level of motivation towards the use of elearning. All items received a positive response with the 8 items put forward getting the overall min of 3.93, which is at a high level. Item 5 is the highest item of min value, which is 4.15 , followed by item 8 with min 3.97. Item 5 is the lowest min value item, which is 3.79 , but it is still at a high level. In a conclusion, the student's motivation for willingness the use elearning is high.

Table 4: Mean distribution of students' attitude towards the use of e-learning for Beauty and Spa Therapy Certificate Program and Diploma in Beauty Therapy

\begin{tabular}{|c|c|c|c|c|}
\hline No. & Item & Mean & SP & Level \\
\hline 1 & I like to use e-learning. & 3.93 & .923 & Tinggi \\
\hline 2 & I am comfortable with the use of e-learning. & 3.92 & .917 & Tinggi \\
\hline 3 & I feel good using e-learning. & 3.79 & .908 & Tinggi \\
\hline 4 & I'm interested in using e-learning. & 3.88 & .924 & Tinggi \\
\hline 5 & I get encouragement from lecturers to use e-learning. & 4.15 & .725 & Tinggi \\
\hline 6 & I get encouragement from my peers to use e-learning. & 3.80 & .952 & Tinggi \\
\hline 7 & $\begin{array}{l}\text { I get encouragement from the college administration to use } \\
\text { e-learning. }\end{array}$ & 3.95 & .906 & Tinggi \\
\hline \multirow[t]{2}{*}{8} & I feel e-learning is cost-effective. & 3.97 & .966 & Tinggi \\
\hline & Total Mean & 3.93 & .759 & Tinggi \\
\hline
\end{tabular}

Ho1: There is no significant difference between knowledge level based on Certificate and Diploma in Beauty Therapy Program

The $t$ test is used to assess the null hypothesis 1. The results can be seen in Table 5. Based on the results of the study, the mean knowledge level score for THE STK program is 3.95 is lower than the mean knowledge level score for the DTK program is 4.02. This difference is insignificant considering $(t=.396 ; p>0.05)$. So, this hypothesis is accepted, that is, there is no 
significant difference between the level of knowledge between the STK and DTK programs at the confidence level $\alpha=0.05$.

Table 5: Mean and Deviation of students' knowledge level based on Certificate and Diploma in Beauty Therapy Program

\begin{tabular}{|l|l|l|l|l|l|}
\hline Semester & $\mathbf{N}$ & Mean & Standard Deviation & T-value & Significant Level \\
\hline STK & 52 & 3.95 & .606 & .628 & .357 \\
\hline DTK & 40 & 4.02 & .656 & & \\
\hline
\end{tabular}

Ho2 There is no significant difference between student attitude levels based on the Certificate and Diploma in Beauty Therapy program.

The $t$ test is used to assess the null hypothesis 2 . Based on Table 6 , the results of the study found that the mean score of STK is 4.00 is slightly higher than the mean score of DTK, which is 3.88. This difference is insignificant considering $(t=.396 ; p>0.05)$. Therefore, the null hypothesis is accepted, i.e., there is no significant difference in student attitude between STK and DTK towards the use of e-learning at confidence level $\alpha=0.05$.

Table 6: Mean and Standard Deviation of students' attitude levels based on Certificate and Diploma in Beauty Therapy Program

\begin{tabular}{|l|l|l|l|l|l|}
\hline Semester & $\mathbf{N}$ & Mean & Standard Deviation & T-value & Significant Level \\
\hline STK & 52 & 4.00 & .611 & .396 & .064 \\
\hline DTK & 40 & 3.88 & .760 & & \\
\hline
\end{tabular}

Ho3 There is no significant difference between motivation based on the Certificate and Diploma in Beauty Therapy program.

This null hypothesis 3 is to test whether there is a significant difference between students' motivations based on the Beauty Therapy Program. In this study, the program consists of Certificates and Diplomas. The t-test has been used to test whether there is a significant difference between the motivation of the student between the Certificate of Beauty Therapy and the diploma in Beauty Therapy. Inference analysis found that there was no significant difference between the motivation of the students according to the STK and DTK students. This is because ( $t=.388 ; p>0.05)$. Therefore, the null hypothesis is accepted, there is no significant difference in student motivation between STK and DTK students at the confidence level $\alpha=0.05$.

Table 7: Mean and Deviation standards the students' motivation level based on the Certificate and Diploma in Beauty Therapy Program

\begin{tabular}{|l|l|l|l|l|l|}
\hline Semester & $\mathbf{N}$ & Mean & Standard Deviation & T-values & Significant Level \\
\hline STK & 52 & 3.99 & .681 & .388 & .098 \\
\hline DTK & 40 & 3.85 & .853 & & \\
\hline
\end{tabular}




\section{Discussion}

According to the first research objective, students of the STK and the DTK have a good degree of understanding in the use of e-learning.. Although students in the STK and DTK are new to the usage of e-learning, it is obvious that they comprehend the purpose of using e-learning.

1. In conclusion, STK and DTK students have a good degree of understanding of the readiness to use e-learning. Students understand the value of e-learning in T\&L implementation, including:Know that many learning materials are available through e-learning since lecturers may readily submit all notes and assignments, making them easily accessible to students.

2. Know that e-learning is now a requirement due to the spread of the COVID-19 Pandemic, which makes face-to-face classes impossible.

3. Be aware that e-learning has numerous benefits, including simple access to lecture notes uploaded by lecturers, cost savings due to the elimination of the need to print tasks for delivery, and the development of ICT skills due to the use of a digital platform for T\&L.

1. The findings for the second research objective revealed that students had a positive attitude toward using e-learning. The STK and DTK students at Sungai Petani Community College exhibit the following attitude, based on the high overall mean:Because the majority of lecturers utilise the same platform for e-learning, you should always strive to use it to receive notes and other learning resources.

2. Always take advantage of e-learning options.

3. Are always ready to use e-learning.

1. Furthermore, the following findings for the third research objective revealed that students were highly motivated to use e-learning. Students claim that they are motivated to use e-learning because of the following reasons:Encouragement to use e-learning from instructors, who will teach you how to use the Google Classroom platform to send assignments and receive notes at the start of each session.

2. Consider e-learning to be cost-effective because all assignments can be uploaded to Google Classroom, and students no longer need to print and send assignments in hard copy form.

3. Encouraged by the college administration to adopt e-learning since WIFI access is available in colleges for students who do not have enough Internet data or who do not have Internet access in their dorms or at home.

The results of the fourth research objective revealed that there is no significant difference in the degree of knowledge, attitude, or motivation of STK and DTK students toward the usage of e-learning. This demonstrates that both groups of students are prepared to use e-learning in terms of knowledge, attitude, and motivation. Students have no problems using e-learning implemented by STK \&DTK instructors with this configuration. These three factors - knowledge, attitude, and motivation - are significant elements towards the application of e-learning, as indicated in previous research by (Abd Manaf et al., 2015; Doman, 2017; Ibrahim et al., 2016; Lapammu and Mahamod, 2018). 


\section{Conclusion}

The researchers' goals of assessing the readiness of students attending STK and DTK courses in terms of knowledge, attitude, and motivational level in e-learning readiness were met through this study. Students display a high degree of knowledge for the first goal. This indicates that they are prepared to use e-learning. Their willingness to adopt e-learning can assist them in improving their academic performance. The availability of e-learning was also seen favourably by pupils. Students also demonstrated initiative in their quest for information. The findings reveal that the student's motivation is also very high. This phenomena may influence a student's readiness to employ e-learning in a favourable way. A statement in the motivational element that displays the highest mean is that professors encourage me to use e-learning by showing me how to use the Google Classroom platform to send assignments and receive notes at the start of a session. This is related to statements eight and seven, in which students can find e-learning cost-effective because all assignments can be uploaded to Google Classroom, and students no longer have to print and send assignments in the form of hard copies, and statement eight, in which students were encouraged to use e-learning by the college administration because WIFI access was provided in college. The combination of these three characteristics has a significant favourable impact on student motivation in the presence of e-learning. Overall, KKSP students enrolled in STK and DTK courses are prepared to use e-learning. Future research should focus on community college lecturers' propensity to adopt e-learning or hybrid learning, as well as how they use e-learning programmes or platforms and the types of learning methodologies they employ.

\section{References}

Abd Manaf, S. Z., Din, R., Hamdan, A., Salleh, M. N. S., Kamsin, I. F., \& Abdul Aziz, J. (2015). Penggunaan komputer dan Internet Web 2.0 dalam kalangan generasi Y pelajar universiti. Journal of Advanced Research Design, 7(1), 10-18. Retrieved from http://www.myjurnal.my/public/article-download.php?id=102723

Bernama. (2020). Cabaran mengajar dalam talian. Sinar Harian. Retrieved from https://www.sinarharian.com.my/article/76874/BERITA/Nasional/Cabaran-mengajardalam-talian

Doma, N. (2017). Implikasi Google Apps dalam pengajaran dan pembelajaran pelajar pesisir UTHM (Unpublished master's thesis). Universiti Tun Hussein Onn Malaysia.

Gillett-Swan, J. (2017). The challenges of online learning supporting and engaging the isolated learner. Journal of Learning Design Special Issue: Business Management, 10(1), 20-30. Retrieved from https://files.eric.ed.gov/fulltext/EJ1127718.pdf

Hamat, M., Mahlan, S. B., \& Ch'ng, P. E. (2020). Adaptasi pengajaran dan pembelajaran secara maya dalam kebiasaan baharu semasa pandemik COVID-19. SIG: e-learning@CS, 23-30. Retrieved from https://appspenang.uitm.edu.my/buletin\%20jskm/20202/Articles/ADAPTASI\%20PENGAJARAN\%20DAN\%20PEMBELAJARAN\%20SECARA\%20MA YA\%20DALAM\%20KEBIASAAN\%20BAHARU\%20SEMASA\%2OPANDEMIK\%20COVID19.pdf

Ibrahim, H., Abu Hassan, N., \& Othman, S. N. (2016). Kesediaan pelajar Politeknik Sultan Azlan Shah terhadap penggunaan e- learning. National Innovation and Invention Competition Through Exhibition (iCompEx'16), 1-7. Retrieved from https://www.academia.edu/23018492

Krejcie, R. V., \& Morgan, D. W. (1970). Determining sample size for research activities. Educational and Psychological Measurement, 30(3), 607-610. doi: 


\section{$10.1177 \% 2 F 001316447003000308$}

Kurniawansyah, A. S., \& Siswanto, S. (2020). Kolaborasi Whatsapp Group, Zoom Cloud Meeting, Dan Google Drive sebagai formula dalam pelaksanaan kegiatan perkuliahan online di masa pandemi COVID-19. Jurnal Media Infotama,16(2). doi: 10.37676/jmi.v16i2.1155

Lapammu, S., \& Mahamod, Z. (2018). Tahap pengetahuan, sikap dan kesediaan pelajar tingkatan 4 terhadap penggunaan pembelajaran persekitaran maya VLE FROG dalam pembelajaran Bahasa Melayu. Jurnal Pendidikan Bahasa Melayu - JPBM, 8(1), 53-62. Retrieved from http://journalarticle.ukm.my/11836/

Ouma, R. L. (2020). Switching to SIDE Mode"-COVID-19 and the adaptation of computer mediated communication learning in Kenya. Proceedings of the 18th International Research Association for Interdisciplinary Studies (RAIS) Conference, 94-103. Retrieved from https://ideas.repec.org/s/smo/apaper.html

Sarvestani, M. S., Mohammadi, M., Afshin, A., \& Raeisy, L. (2019). Students' experiences of $e-$ learning challenges: A phenomenological study. Interdisciplinary Journal of Virtual Learning in Medical Sciences, 10(3), 1-10. Retrieved from https://ijvlms.sums.ac.ir/article_45841_bf6d528b06b2a94c32859036cc4a3154.pdf

Siddiquah, A., \& Salim, Z. (2017). The ICT facilities, skills, usage, and the problems faced by the students of higher education. EURASIA Journal of Mathematics Science and Technology Education, 13(8), 4987-4994. doi: 10.12973/eurasia.2017.00977a

Suri, A., Subagyo, F. A. K. D., \& Irwansyah, I. (2021). Computer-mediated communication dan manajemen kesan pada pembelajaran elektronik mahasiswa di masa pandemi Covid19. SALAM: Jurnal Sosial dan Budaya Syar-i, 8(1). doi: 10.15408/sjsbs.v8i1.19079

Valverde-Berrocoso, J., Garrido-Arroyo, M. D. C., Burgos-Videla, C., \& Morales-Cevallos, M. B. (2020). Trends in educational research about e-learning: A systematic literature review (2009-2018). Sustainability, 12, 5153. doi: 10.3390/su12125153

Yahaya, N., \& Ling, N. N. (2011). Kesediaan penggunaan e-learning di kalangan pelajar tahun kedua kursus Sarjana Muda Sains, Komputer Serta Pendidikan, Fakulti Pendidikan, Universiti Teknologi Malaysia - satu tinjauan. Jurnal of Educational Social Science, 1. 121140. Retrieved from http://eprints.utm.my/id/eprint/12147/

Yahaya, S. (2018). The key challenges of implementing e-learning in engineering training programs. Journal of the Society of Automotive Engineers Malaysia, 2(3), 324-328. Retrieved from http://ijedict.dec.uwi.edu/include/getdoc.php?id=4575...472...pdf 